\title{
JOURNAL.RU
}

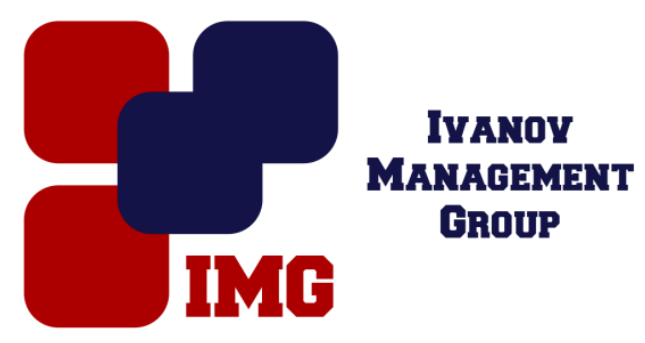

Глухова Е.В.

Российский государственный профессионально-педагогический университет Екатеринбург, Россия

doi: $10.18411 / 1 \mathrm{j}-30-06-2017-45$

idsp 000001:1j-30-06-2017-45

\section{Особенности воспитания и образованияобучающихся в социокультурной среде Абхазии}

Актуальность данной статьи обусловлена необходимостью выявления аспектов воспитания и обучения детей в абхазской семье. Исследование дает возможность сравнительного анализа народов Абхазии и России, основываясь на толерантном подходе.

Говоря о воспитании и обучении детей в абхазской семье, мы говорим прежде всего о тех аспектах, которые не совсем привычны для семей средней полосы России. Основой воспитания и обучения становятся традиционные устои. С самого раннего возраста обучение ведется на двух языках: русском и абхазском, что создает дополнительные трудности для ребенка, но в то же время развивает гибкость мышления и кругозор. Таким образом, можно выделить билингвизм (двуязычие) как одну из особенностей обучения и воспитания ребенка. Также необходимо отметить, что как устная, так и письменная речь на двух языках развита в одинаковой степени и к моменту поступления в школу, ребенок свободно владеет ими. Небольшой особенностью является особый местный акцент, неправильное употребление окончаний и падежей, что исправляется в процессе обучения в школе. Интересным фактом является разговор на двух языках одновременно как в процессе обучения, так и в бытовой среде, то есть начало предложения может быть на русском языке, а окончание на абхазском и наоборот. При этом, отсутствуют какие-либо разделения для облегчения усвоения двух языков одновременно, а именно: не применяется разделение языков по сферам (например, про одежду говорим только на 
абхазском языке, а про пищу-на русском), гендерное разделение также отсутствует (например, мама говорит на русском, а отец-на абхазском). Важным фактором является то, что ребенок, разговаривая на двух языках одновременно, не чувствует себя оторванным от социума, не имеет нужды ставить психологические барьеры, а в подростковом возрасте не чувствует себя ущербным, так как билингвизм-обычное явление для Абхазии. У ребенка существуют партнеры по общению-сверстники, учителя, родители, которые не только дают возможность слышать различные варианты языков, конструкции предложений, манеру произношения, то и поддерживают ребенка психологически.

При поступлениив школу, обучение ведется на двух языках, при этом у родителей есть возможность выбрать, в каком именно классе необходимо обучение: с углубленным изучением русского или абхазского языка. Кроме этого, в школе существует и привычное для нас разделение на математическое и гуманитарное направление обучения.

Еще одной особенностью при воспитании ребенка является почитание старшего поколения. В одном доме могут проживать несколько семей, включая бабушек и дедушек. Такой культ определенным образом связан с религией. Согласно верованием абхазцев все живое является носителем души. Такое убеждение, как и упомянутый выше культ предков, есть часть автохтонной религии или, как ее еще называют, «индигенная религия». Автохтонная религия (от греч. «туземный, коренной»)- религиозные верования и ритуалы, возникшие в этнической среде без внешнего инорелигиозного влияния и развившиеся на основе свойственных группе этнических особенностей [1]. В воспитании детей культ предков является одной из самых главных особенностей.

Но несмотря на то,что современное образование в Абхазии тесно связано с культурными особенностями, огромное влияние оказывает российская образовательная система. После завершения грузино-абхазской войны в 1993 году, Абхазия приняла решение о переходе на Российские образовательные стандарты. Образовательные учреждения Абхазии разделяются на начальные, средние и неполные средние. Неполные средние школы находятся в основном в небольших населенных пунктах.

В Сухуме, столице республики, действуют пара частных общеобразовательных школ. Есть лицей и интернаты при средних школах. Но выпускники окончившие школу без дополнительной подготовки не могут поступить в высшие учебные учреждения в России. Для развития системы 
образования и выведения ее на современный уровень выполняются следующие контрольные задачи: внедрение единых образовательных стандартов для всех учебных заведений республики,упорядочение системы отбора абхазских абитуриентов, поступающих в российские вузы по целевым направлениям, выполнение подписанного ранее Договора о союзничестве и стратегическом партнерстве между РА и РФ, а также создание и осуществление образовательных проектов на всех уровнях образования [3].

Такие стратегические методы позволят не только укрепить сотрудничество между Россией и Абхазией, а также повысить уровень и качество образования обучающихся, не вырывая их из социокультурного контекста что является основным и таким важным при рассмотрении системы образования Абхазской республики.

$* * *$

1. Горбунова, Е.В. Пути реализации концепции модернизации Российского образования на период до 2010 года [Текст] / Е.В. Горбунова // Образование и наука. Известия Уральского отделения Российской академии образования, № 4 (22). - 2003. - C. 118-121.

2. Дарвиш, О.Б. Возрастная психология [Текст] / О.Б. Дарвиш. - М. :Владос, 2005. $264 \mathrm{c}$.

3. Культура веры. [Электронный ресурс] - Режим доступа: www.religiocivilis.ru(дата обращения: 19.06.2017)

4. Научно-исследовательский институт «Прометей» [Электронный ресурс]. - Режим доступа: http://old.mediaartlab.ru/db/inst.html?id=72 (дата обращения: 19.06.2017) 